\title{
Introduction
}

\section{Cities: an Anthropological Perspective}

By Andrew Irving (Department of Psychiatry and Behavioural Sciences, University College of London and Royal Free Hospital).

'The city is composed of different kinds of men; similar people cannot bring the city into existence' (Aristotle).

'What is the city? How did it come into existence? What processes does it further; what functions does it perform; what purposes does it fulfil?' (Lewis Mumford).

'Through the city the sins of the fathers are visited upon the children; every city has a history and a rate of interest' (Norman Brown).

Cities are central to anthropological practices. As anthropologists we continually find ourselves living in or being drawn to cities without necessarily considering ourselves 'urban anthropologists'. Partly this is because most university anthropology departments are located in cities, but also because even when fieldwork takes place in towns, villages and rural areas, cities still provide the 'gateway' to the field. Not just in the physical sense of airports, train and bus stations but also in terms of communications, government offices, obtaining research permits, searching archives, accessing literature and information, maintaining university contacts and engaging with local academics and experts.

On arrival in the field it often becomes noticeable the extent to which rural towns and villages are constructed against the nearest city. Rural inhabitants' own understandings of themselves continually exist in relation to nearby cities, with their potential to symbolise modernity, allow alternate social spaces, create different possibilities for personhood and social life and range of diverse phenomenological backgrounds and neighbourhoods. Moreover as Aristotle suggested, the very existence of cities is dependent upon the differences between the persons who inhabit them. It is a foundational diversity that is responsible for bringing the many different types of city into being; the discursive city, the mythical city, the physical city, the poetic city, the underground city, the late-night city, the working city, the women's city and the men's city. To this list we might also add Low's categories in the summary of urban anthropology for the Annual Review of Anthropology: the ethnic city, divided city, gendered city, contested city, de-industrialised city, modernist city, 
postmodern city, fortress city, sacred city and traditional city (1996). Thus the city does not exist in an individual's mind or 'out there' as an objective physical landscape but as a collective entity that gathers people's emotions and memories, mixes them with architecture and elicits distinctive practices and ways of being being. Or put another way the city is not simply architecture alone, but a curious melding of 'flesh and stone' (Sennett 1994).

For this special edition of the Anthropology Matters journal, we invited papers on all aspects of metropolitan life and practice, including those concerning the ways in which anthropologists inhabit and situate themselves within urban environments during fieldwork. The result is a series of articles that offers a number of fresh and invigorating approaches towards the city and the particular processes involved in conducting fieldwork in the different parts of the city. The contributors not only wrote about a range of different subjects (the homeless, performers, commuters, financiers, violent communities and virtual citizens) in various urban environments (slums, banks, streets, squares and train-stations) in cities across the world (Donetsk, Rio, Bombay, London, Frankfurt, Berlin and Tokyo), but also come from different parts of the world themselves. The world has always been interconnected through wars, tourism, migration and so forth but perhaps never with the same intensity as over the last century, a century which also witnessed the rapid expansion of urban centres. Cities are often the important hubs that facilitate, maintain and encourage interactions between persons in different parts of the world. Indeed this site and journal are a product of such connections, and it is an interesting and open question as to whether any of the subjects or authors of these papers have crossed paths in other places or contexts.

In Iban Ayesta's article we encounter Fahrid, a homeless man in Berlin obsessed with studying the insects he sees on the ground around him. Ayesta draws attention to the international finance workers who walk by Fahrid every day on their way to work; in contrast, Ayesta the anthropologist stops and studies. In doing so Ayesta creates a strange parallel with his object of study only at one stage removed. Fahrid is an entomologist manqué who intensely and obsessively studies the insects on the ground. Ayesta meanwhile is an anthropologist manqué who is of course studying Fahrid. Ayesta wonders whether he is morphing from an anthropologist into entomologist, and like an insect himself, becomes caught between the two disciplines, raising questions about the status of the anthropologist and the processes of anthropological research.

The objects of study in Fiona Moore's article are some of those very international finance workers who walk past Ayesta's homeless man. And it would be a strange coincidence indeed-although not beyond the realms of possibility considering that Moore's focus of study is German finance workers-if some of her subjects ever walked past Fahrid or even Ayesta himself as he was carrying out his research. Moore's international financiers straddle two cities; Frankfurt and London, the two most important financial centres in Europe; and their natural habitats are offices, airports, banks and bars. They engage with the city and its inhabitants through various symbolic forms, the most obvious being money, but also through their dress and the places they frequent.

Slums are a by-product of both wealth and poverty. For whilst it could be said that slums are what happen when people's 'homeless' state becomes more permanent, that semi-permanence is itself maintained by the proximity to wealth and places such as 
financial districts with their endless appetite for cleaners, kitchen workers and so forth. Atreyee Sen's article explores some of the dilemmas and difficulties of not only conducting research, but also living in a slum. The slum in question is located in Mumbai (Bombay), a city where slums have been the focus of intense political activity and violence. The urban conflicts she studies (and experiences) are in part generated by religion and poverty but unusually the agents involved are women and mothers who have created a powerful, semi-formalised network and organisation which has almost become the main law in and around the slums where Sen worked.

Many thousands of miles from Mumbai lies Rio de Janeiro, a city renowned for its outdoor life and public places. Ethel Pinheiro and Cristiane Duarte consider how street-artists and performers have used the city's open spaces and largos over the last 50 years to open up dialogues with members of the public. The authors' main focus is a well known and important open space in Rio called Largo de Carioca, where they observe the many interactions between audience and performer. The largo is a place of dialogue and exchange: people form 'circles' of interaction that spiral out and enter into Rio's 'city-talk', and the largo comes to symbolise the city itself. Moreover they document a period in Brazil's history that has witnessed military dictatorship and its overthrow, and yet throughout these changes the Largo de Carioca retains much of its essential character and openness by way of the art and performance that is found there.

Ray Lucas considers a very different public place; Shinjuku train station in the centre of Tokyo. Here the public's performance is of a different order to those found in Brazil's squares and largos. It is an order that Lucas tries to access not merely through conventional academic theory and familiar literary characters, such as the flâneur, but also more creatively through dance and drawings. For example, when Lucas takes the reader around Shinjuku station, he does not only refer to important theorists such as Walter Benjamin he also uses Laban notation, a form of movement notation frequently used in ballet. Theory, drawing and notation are applied to the practices and movements of commuters walking through the station.

Julia Holdsworth considers the relationship between memory, ritual and collective identity in post-Soviet society. The city in question is Donetsk, a heavily industrialised city in East Ukraine where recent times have witnessed numerous political and social changes. Donetsk's citizens do not deny the past as summed up by one person 'Over there they are taking down their Lenins, even changing the names of their streets. Why? Here we do not pretend that things that happened have not happened'. Thus the city's surfaces look to past, present and future. Street names remain the same as in the Soviet era, but are now written in the Ukrainian language, whilst billboards sell goods that are economically unattainable but nevertheless gesture towards local aspirations and future possibilities.

The city in Denise Maia Carter's paper is a virtual city known as 'Cybercity'. The population in Cybercity on Friday $14^{\text {th }}$ November 2003 stood at 1,051,437 citizenswhich by conventional measures would make it the $389^{\text {th }}$ largest city in the world. Her fieldwork took place between September 1999 and March 2003, during this time she 'lived' and 'worked' in Cybercity, involved herself in its community and became embedded in a series of social relationships that seem to be organised more perfectly than in conventional everyday life. Carter's daily life in Cybercity raises questions about our existing anthropological theories and definitions about cities and offers a range of new possibilities and perspectives about what constitutes a city. 
Together these papers offer a number of new perspectives to Mumford's questions at the beginning of this introduction 'What is the city? How did it come into existence? What processes does it further; what functions does it perform; what purposes does it fulfil?' Throughout this collection of articles we occasionally witness some idiosyncratic and quirky uses of language. The metaphors and linguistic expressions that are used are borne out of difference and in editing the articles we thought it would be wrong to homogenise and standardise the authors' linguistic expressions and turn them into standard academic English. Not only would this impose a unitary framework of understanding of what the city means, but it would also be a betrayal of the fundamental diversity of cities themselves. For like the city itself, within these gaps in language lie different possibilities for discovering and understanding what it means to experience, dwell and live in 'the city'...

\section{References}

Brown, N. O. 1970. Life against death. London: Sphere.

Low, S. 1996. The Anthropology of Cities: Imagining and Theorising the City. Annual Review of Anthropology. 25: 387-399.

Mumford, L. 1961. The City in History. London: Pelican.

Sennett, R. 1994. Flesh and Stone: The body and the city in western civilisation. London: Faber and Faber.

\section{About the author}

Andrew Irving is a research fellow in the Department of Psychiatry and Behavioural Sciences, University College of London and Royal Free Hospital, where he is working on a project that seeks to understand the psychological and emotional journey people make after diagnosis with cancer. Previously he has conducted fieldwork amongst people living with HIV/AIDS in Kampala and New York, and is particularly interested in those moments where time and death emerge into everyday life. His award-winning PhD is entitled 'Life Made Strange; A Comparative Study of How HIV/AIDS Affects Perception of Time, Existence and Otherness', and was completed at the School of Oriental and African Studies in 2002. 